\section{Standard weights in ancient Andes}

SIR - New evidence suggests that a standardized measure of weight was used in the prehispanic Andes. Small, prehispanic beam balances have been found throughout the are $\mathrm{a}^{1-5}$, but were thought to have been used with internally consistent unique weight sets to measure proportions only. No standardization was thought to have existed ${ }^{6,7}$. I have found that the weights of four copper ingots from various locations on the Peruvian coast correspond to regular multiples of a ideal weights of 50 and $100 \mathrm{H}$ (see table). This accuracy is about what one would expect for ingots made, as these were, by remelting a carefully weighed quantity of copper prills ${ }^{8}$. Some copper would have been lost in the formation of crucible slag. Some impurities, notably iron, accounting for a few per cent of the prills' weight, would have segregated and been removed with the slag. These variables would have made more precisely replicated ingot weights impossible. The two Cerro Huaringa ingots, found together, could reflect an ancient pairing to make up a mass of copper weighing exactly $150 \mathrm{H}$.

So far, only two additional copper

\begin{tabular}{cccc}
\hline & \multicolumn{4}{c}{ PLANO-CONVEX INGOT WEIGHTS } \\
\hline Ingot & $\begin{array}{c}\text { Metric weight } \\
(\mathrm{g})\end{array}$ & $\begin{array}{c}\text { Andean weight } \\
(H)\end{array}$ & $\begin{array}{c}\text { Approximation } \\
(H \pm \%)\end{array}$ \\
Cerro Huaringa & & & \\
BG 80-1 & 182 & 47.9 & $50-4.2$ \\
BG 80-2 & 399 & 105 & $100+5.0$ \\
BG 80-1 + BG 80-2 & 581 & 153 & $150+1.9$ \\
Chan Chan & & & $100+1.6$ \\
AMNH B/5200 & 386 & 102 & $300+3.5$ \\
La Lengua & & 289 & 3 \\
Ref. 11 & 1,100 & 289 & \\
\hline
\end{tabular}

unit originally proposed by Nordenskiöld ${ }^{5}$ for prehispanic weights.

Most known Andean weights date to the Postconquest period and consist of simple pebbles carefully selected to correspond to the Spanish colonial system of onzas and castellanos. Nordenskiöld, however, identified 13 weights that did not conform to the Spanish system: one set of nine pebble weights in a cloth bag from Pachacamac, Peru; and four individual weights from various Andean locations. $\mathrm{He}$ found their weights to be multiples of a unit he called $H$, perhaps for huarcu, the word for weight in both Quechua and Aymará. The heaviest of the nine pebble set weighs $25 \mathrm{H}$; the other eight together weigh $25 \mathrm{H}$. The mean value of $H$ is $3.80 \pm 0.058 \mathrm{~g}$.

Nordenskiöld's other weights, unfortunately, are vaguely provenanced and perhaps selectively chosen. Nevertheless, they include two pebbles $(H=3.71$ and $3.89 \mathrm{~g}$ ) from a "work-basket on the Peruvian coast", a somewhat oxidized lead weight $(H=3.75 \mathrm{~g})$ from "Baranca", and a pierced quartz stone $(H=3.88 \mathrm{~g})$ from Pinal, Ecuador. Including these additional finds would yield a mean $H$ of $3.80 \pm 0.067 \mathrm{~g}$.

More recently, I found two plano-convex ingots of arsenical copper at the late prehistoric copper smelting site of Cerro Huaringa on Peru's north coast. These ingots approximate to ingots that closely resemble the Cerro Huaringa ingots have been found. Both approximate to ideal weights, 100 and 300 $H$, respectively. The former, in the American Museum of Natural History ${ }^{9,10}$, came from a grave in the Chimú capital of Chan Chan on Peru's north coast. Caley and Easby ${ }^{11}$ acquired the latter on the south coast, at "La Lengua", in the Ingenio valley of Ica Province. It was wrapped in a warp-faced, plain-weave cotton cloth, with the alternating plain and barred stripes most common in textiles between $\mathrm{AD} 1200$ and 1535 .

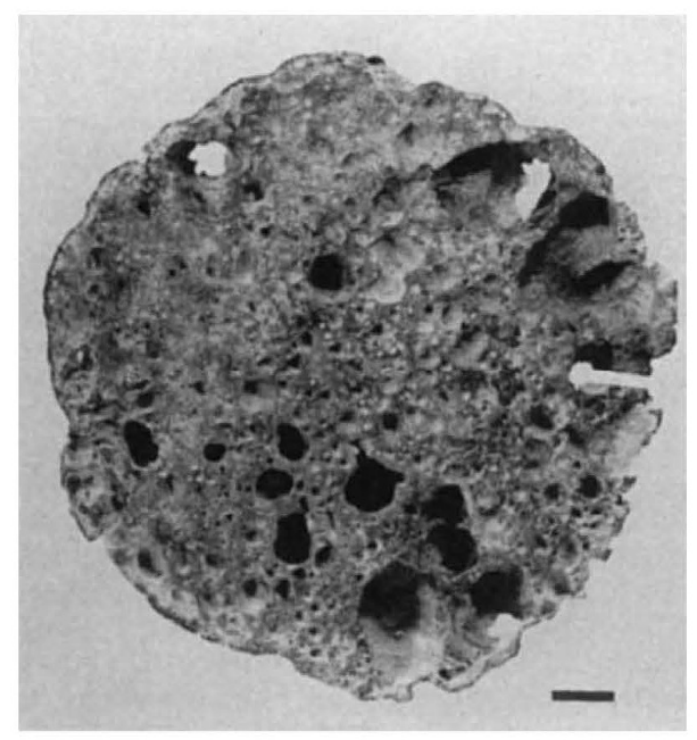

A plano-convex ingot of arsenical copper found at Cerro Huaringa, Peru. The ingot is designated BG 80-2. Scale bar, $1 \mathrm{~cm}$. (Photo by N. Hartmann.)
Together, these weights and ingots suggest the existence of a system of standardized weights used from Ecuador to Peru's south coast. A late prehistoric date is indicated by the late textile accompanying the south coast ingot, and the late occupation of Cerro Huaringa's smelting workshops (AD 1100-1535) and Chan Chan (AD 1000-1470). The Chan Chan ingot predates the Inca conquest of the Chimú Empire in $\mathrm{AD} 1470$, and so the system was not an Inca innovation. While the extent and antiquity of the system are still obscure, its very existence offers new insights into control of commodities, organization of production and circulation of goods in the prehispanic Andes.

\section{Stephen M. Epstein}

Department of Anthropology,

University of Pennsylvania,

Philadelphia,

Pennsylvania 19104,

USA

\footnotetext{
1. Nordenskiöld, E. J. Soc. Am. Paris 13, 169-175 (1921)

2. Rostworowski de Diez Canseco, M. in Actas del II Congreso Nacional de História 1953 Vol. 2, 102-115 (Lima, Peru, 1960).

3. Baessier, A. Ancient Peruvian Art (transl. Keane, A.H.) Plate 161 (Dodd, Mead, New York, 1902-1903).

4. Schmidt, M. Kunst und Kultur von Peru 544 (Propyläen, Berlin, 1921).

5. Nordenskiöld, E. Man 30, 215-221 (1930).

6. Bennett, W. C. in Handbook of South American Indians Vol. 5 (ed. Steward, J.) 601-610 (Smithsonian Institution, Washington, 1949).

7. Rostworowski de Diez Canseco, M. in La tecnologia en el mundo andino: Runakunap Kawsayninkupag Rurasquankunaqa (eds Lechtman, $\mathrm{H}$ \& Soldi, A. M.) 380-405 (Universidad Nacional Autónoma de México, Mexico City, 1981)

8. Epstein, S. M. MASCA J. 2, 57-62 (1982)

9. Meand, C. W. Anthrop. Pap. Am. Mus. nat. Hist. 12 (Pt 2) 16-52 (1915)

10. Petersen, G. G. Mineria y metalurgia en el antiguo Perú (Museo Nacional de Antropologia y Arqueologia, Lima, 1970).

11. Caley, E. R. \& Easby, D. T. Jr Am. Antig. 25, 59-65 (1959).
}

\section{The 'St Jude' gambit}

SIR - Oliver Goodenough and Richard Dawkins (Nature 371, 23-24; 1994) have overlooked the fact that prior exposure to an appropriate mind virus may be a prerequisite for susceptibility to infection by another mind virus.

They themselves report the "experiencing of waves of mild, irrational anxiety on deciding not to comply" with the postal parasite's instructions. These symptoms disclose a prior infection, a 'meme', that was successfully implanted in them. It required a challenge from the St Jude virus to uncover the meme. Perhaps further taxonomic refinement will show that all memes are mind viruses, but not all mind viruses are memes.

Ian Dunn

48 Frederick Street,

Hornsby,

New South Wales 2077,

Australia 